\title{
REDUCTION OF WHITE MOLD LEVEL ON SOYBEAN BY FUNGICIDE MANAGEMENT STRATEGIES
}

\author{
REDUÇÃO DO NÍVEL DE MOFO-BRANCO NA SOJA PELO MANEJO DE \\ FUNGICIDAS
}

\section{Carlos Rafael WUTZKI ${ }^{1}$; David de Souza JACCOUD FILHO² ; Ayrton BERGER NETO $^{3}$; Hamilton Edemundo TULLIO ${ }^{3}$; Fernando Cezar JULIATTI ${ }^{4}$; Aguinaldo José do NASCIMENTO5;}

1. Agronomist, PhD student, Universidade Estadual de Ponta Grossa - UEPG, Ponta Grossa, PR, Brasil. 2. Biologist, Agronomist, Professor, PhD., Departamento de Fitotecnia e Fitossanidade - DEFITO - UEPG - Ponta Grossa, PR, Brasil. dj1002@uepg.br; 3. Agronomist, MSc., UEPG, Ponta Grossa, PR, Brasil; 4. Agronomist, Professor, PhD., Instituto de Ciências Agrárias - ICIAG, Universidade Federal de Uberlândia - UFU, Uberlândia, MG, Brasil; 5. Agronomist, Professor, PhD., Departamento de Bioquímica, Universidade Federal do Paraná - UFPR.

\begin{abstract}
The objective of this study was to verify the efficiency of the control of white mold on soybean with the use of fungicides applied alone and in rotation, at different growth stages and in a mixture of two active ingredients at three locations: Arapoti, PR, Mauá-da-Serra, PR and Pinhão, PR, Brazil. The fungicides used were carbendazim $(\mathrm{Ca})$, thiophanate methyl $(\mathrm{Tm})$, procymidone $(\mathrm{Pr})$ and fluazinam $(\mathrm{Fl})$. The experiments consisted on 17 treatments and 4 replications in a randomized block design. The analyzed variables were severity, incidence, number of sclerotia and yield. Mauá-da-Serra and Pinhão presented the highest incidences (31\% and $29.8 \%$ in the control, respectively). At these two locations most of treatments with fungicides decreased the incidence and production of sclerotia, when compared to control; however, no differences in terms of yield were observed. Arapoti presented the lowest incidence $(15.8 \%$ in the control) where most of treatments with fungicides did not present differences for the variables incidence, production of sclerotia and yield, when compared to the control. No differences were also observed for severity in any of three locations. In conclusion, fungicides applied in soybean areas with historically white mold incidence up to $31 \%$ can reduce the disease incidence and sclerotia production levels.
\end{abstract}

KEYWORDS: Sclerotinia sclerotiorum (Lib.) De Bary. Glycine max L. Sclerotia. Fungicides.

\section{INTRODUCTION}

Sclerotinia sclerotiorum is a polyphagous and aggressive fungus; it hosts over 408 species of plants such as soybean, sunflower, canola, peas, beans, alfalfa, tobacco, tomato and potato (BOLAND; HALL, 1994). On soybean, the disease is known as white mold and it can cause damage of up to $70 \%$, as found by Jaccoud Filho et al. (2010a) in the state of Paraná, Brazil. It is a disease that is difficult to control because the $S$. sclerotiorum fungus produces resistant structures called sclerotia, which can remain viable in the soil for periods of 5 (COLEY-SMITH; COOKE, 1971) to 10 years (FERREIRA et al., 1979). These sclerotia can germinate carpogenically and can produce up to 2 million ascospores in a period of 10 days, spreading over a distance of up to $50 \mathrm{~m}$ (STEADMAN, 1983).

Due to the characteristics of white mold on soybean, several steps should be taken to control it, such as crop rotation; covering the soil with dry biomass made from winter crops; wider row spacing at the time of sowing; less plant density; the choice of cultivars that are less susceptible to pathogen; the use of healthy and treated seeds; as well as appropriate sowing dates and biological control (GRAU; HARTMAN, 1999; ALMEIDA et al., 2005; GOULART, 2005; JACCOUD FILHO et al., 2010b; ZENG et al., 2012). However, in areas with a high potential for inoculum, and favorable conditions for the development of the pathogen, the effectiveness of these methods alone is low (MUELLER et al., 2002). In such cases, the application of fungicides may decrease the infection of soybean by disease and reduce the inoculum production for the next harvest.

The chemical control of white mold on soybean is efficient when it is applied at the correct time, at an adequate volume, and using appropriate spray nozzles (MUELLER et al, 2002; JULIATTI; JULIATTI, 2010). It is important to achieve good penetration of the spray in the canopy, and adequate wetting of the lower and middle third of the crop, thereby mainly affecting the flowers during the soybean flowering period, which are the initial energy source for white mold infection, coinciding with the release of ascospores by the pathogen (ABAWI, et al., 1975; SCHWARTZ; STEADMAN, 1978; MUELLER et al, 2002). 
However, the continuous use of the same active ingredient can cause resistance to the pathogen, as shown with carbendazim (YIN et al., 2010) and methyl thiophanate (MUELLER et al., 2002); consequently, it is important to rotate the different active ingredients.

Thus, this study verified the efficiency control of white mold on soybean using different fungicides applied alone and in rotation at different stages of growth, and using mixtures of two active ingredients at locations: Arapoti, Mauá-da-Serra and Pinhão, all in Paraná state, Brazil.

\section{MATERIAL AND METHODS}

It were performed three experiments in areas naturally infested with white mold during the 2011-12 crop season in the municipalities of Arapoti, PR, Mauá-da-Serra, PR and Pinhão, PR, in Brazil.

Prior the tests, soil samples were collected to quantify the number of sclerotia at four points of
WUTZKI, C. R. et al.

$0.25 \mathrm{~m}^{-2}$ at a depth of $5 \mathrm{~cm}$, according to the methodology proposed by Jaccoud Filho et al. (2010a). This resulted in the following: Arapoti had 55 sclerotia $\mathrm{m}^{-2}$, Mauá-da-Serra had 452 sclerotia $\mathrm{m}^{-}$ 2 and Pinhão had 149 sclerotia $\mathrm{m}^{-2}$. In Arapoti the variety used was BMX Turbo RR, which was sown on 27/11/11 with 16 seeds $\mathrm{m}^{-1}$. In Mauá-da-Serra the variety used was NA 5909 RR, which was sown on 30/10/2011 with 14 seeds $\mathrm{m}^{-1}$, and in Pinhão the variety used was BMX Apolo RR, which was sown on 10/11/2011 with 12 seeds $\mathrm{m}^{-1}$. All varieties used have indeterminate growth habit and susceptibility to white mold on field trials (PIERRE, 2015). In all three locations the spacing used was $45 \mathrm{~cm}$ between rows and plant population was settled as technical recommendations for the variety, region and sowing date. The fertilization and control of weeds, insects and other diseases were carried out as recommended by the technical assistance provided by the producer of each farm. The experimental design was randomized blocks with 17 treatments and 4 repetitions (Table 1).

Table 1. Treatments, growth stages, applications and doses used in chemical control experiments conducted in Arapoti, Mauá-da-Serra and Pinhão, 2011-12 crop season.

\begin{tabular}{|c|c|c|c|c|c|c|}
\hline \multirow{2}{*}{\multicolumn{2}{|c|}{ Treatments }} & \multicolumn{5}{|c|}{ Applications } \\
\hline & & 1 & 2 & 3 & 4 & Dosage g.a.i. ha $^{-1}$ \\
\hline 1 & Control & $\mathrm{NT}^{1}$ & NT & NT & NT & NT \\
\hline \multirow{2}{*}{2} & Thiophanate methyl & - & - & $\mathrm{R} 2^{4}$ & $\mathrm{R} 4^{5}$ & 500 \\
\hline & Fluazinam & - & $\mathrm{R} 1^{3}$ & - & - & 500 \\
\hline \multirow{2}{*}{3} & Thiophanate methyl & - & - & $\mathrm{R} 2$ & - & 500 \\
\hline & Fluazinam & - & $\mathrm{R} 1$ & - & $\mathrm{R} 4$ & 500 \\
\hline 4 & Fluazinam & - & $\mathrm{R} 1$ & $\mathrm{R} 2$ & - & 500 \\
\hline 5 & Fluazinam & - & $\mathrm{R} 1$ & $\mathrm{R} 2$ & $\mathrm{R} 4$ & 500 \\
\hline \multirow{3}{*}{6} & Thiophanate methyl & - & - & $\mathrm{R} 2$ & - & 500 \\
\hline & Procymidone & - & $\mathrm{R} 1$ & - & - & 500 \\
\hline & Fluazinam & - & - & - & $\mathrm{R} 4$ & 500 \\
\hline \multirow{2}{*}{7} & Carbendazim & $\mathrm{V} 9^{2}$ & - & $\mathrm{R} 2$ & - & 500 \\
\hline & Fluazinam & - & $\mathrm{R} 1$ & - & $\mathrm{R} 4$ & 500 \\
\hline \multirow{2}{*}{8} & Thiophanate methyl & V9 & - & $\mathrm{R} 2$ & - & 500 \\
\hline & Fluazinam & - & $\mathrm{R} 1$ & - & $\mathrm{R} 4$ & 500 \\
\hline \multirow{2}{*}{9} & Carbendazim & - & $\mathrm{R} 1$ & - & $\mathrm{R} 4$ & 500 \\
\hline & Fluazinam & - & - & $\mathrm{R} 2$ & - & 500 \\
\hline 10 & Fluazinam & V9 & $\mathrm{R} 1$ & $\mathrm{R} 2$ & $\mathrm{R} 4$ & 500 \\
\hline 11 & Procymidone & V9 & $\mathrm{R} 1$ & $\mathrm{R} 2$ & $\mathrm{R} 4$ & 500 \\
\hline 12 & Carbendazim & V9 & $\mathrm{R} 1$ & $\mathrm{R} 2$ & $\mathrm{R} 4$ & 500 \\
\hline 13 & Thiophanate methyl & V9 & $\mathrm{R} 1$ & $\mathrm{R} 2$ & $\mathrm{R} 4$ & 500 \\
\hline
\end{tabular}




\begin{tabular}{rlrllll}
\multirow{2}{*}{14} & Carbendazim & V9 & R1 & R2 & R4 & 250 \\
& Fluazinam & V9 & R1 & R2 & R4 & 250 \\
\hline \multirow{2}{*}{15} & Thiophanate methyl & V9 & R1 & R2 & R4 & 250 \\
& Fluazinam & V9 & R1 & R2 & R4 & 250 \\
\hline \multirow{2}{*}{16} & Carbendazim & V9 & R1 & R2 & R4 & 250 \\
\cline { 2 - 5 } & Procymidone & V9 & R1 & R2 & R4 & 250 \\
\hline \multirow{2}{*}{17} & Thiophanate methyl & V9 & R1 & R2 & R4 & 250 \\
& Procymidone & V9 & R1 & R2 & R4 & 250 \\
\hline
\end{tabular}

${ }^{\mathrm{T}} \mathrm{NT}$ : no treatment; ${ }^{2} \mathrm{~V} 9$ : nine open trifoliates; ${ }^{3} \mathrm{R} 1$ : first open flower; ${ }^{4} \mathrm{R} 2$ : full bloom; ${ }^{5} \mathrm{R} 4$ : full pod developed.

The plots consisted of 7 rows of $6 \mathrm{~m}$ each where applications were conducted using a pressurized $\mathrm{CO}_{2}$ backpack sprayer, with a pressure of 3 bars and a 6 nozzle spray boom (3.0 m length) using Teejet ${ }^{\circledR}$ XR 11002 fan type spray nozzles and a volume of liquid of $200 \mathrm{~L} \mathrm{ha}^{-1}$.

The assessment of the incidence and severity of plants infected by $S$. sclerotiorum was performed using $4 \mathrm{~m}$ of the two central rows of each plot at the R5.5 phenological stage (pods with 75$100 \%$ graining) (FEHR; CAVINESS, 1977). For assessment of severity, the diagrammatic scale proposed by Juliatti and Juliatti (2010) was used.

Prior to harvest, eight infected plants were selected in the two central rows of each plot and were collected for the subsequent quantification of the number of internal and externally attached sclerotia on soybean plants. Using these data, and the incidence of the disease in the plots, it was possible to estimate the number of sclerotia ha $^{-1}$ per treatment.

It were harvested $4 \mathrm{~m}$ in length from the four central rows of each plot, totalling $7.2 \mathrm{~m}^{2}$, and the moisture of grains was adjusted to $13 \% \mathrm{v} / \mathrm{v}$.

All the data were submitted to the Kolmogorov-Smirnov normality test and the nonparametric Kruskal-Wallis and Mann-Whitney-U tests using Statistica software 10.0® (Statsoft@).

\section{RESULTS AND DISCUSSION}

As can be seen from Figures 1A, 2A and $3 \mathrm{~A}$, the highest incidence of $S$. sclerotiorum occurred in Mauá-da-Serra $(31 \%$ in the control treatment) followed by Pinhão $(29.8 \%$ in the control) and Arapoti (15.8\%). These values can possibly be explained by the higher level of contamination in Mauá-da-Serra, given that there were 452 sclerotia $\mathrm{m}^{-2}$ in that area, whereas in Pinhão there were 149 sclerotia $\mathrm{m}^{-2}$ and in Arapoti there were 55 sclerotia $\mathrm{m}^{-2}$. As well as the presence of the inoculum (sclerotia), the weather conditions during the flowering period are crucial in relation to the occurrence of white mold on soybean, since the flowers are used as a source of energy for the germination of ascospore, as well as there being a need for rainwater fall on plants for infection to occur (ABAWI; GROGAN, 1979; NAPOLEÃO et al., 2005).

On average, the cultivars used at the three locations had a flowering period of around 20 days, a period that was used in the analysis of the meteorological data. In Mauá-da-Serra and Pinhão there were higher levels of rainfall (107 and 132 $\mathrm{mm}$, respectively) and higher relative levels of humidity ( 80 and $82 \%$, respectively) compared to Arapoti (20 mm rainfall and $76 \%$ relative humidity) (Annexes 1, 2 and 3). These values can possibly explain the lower incidence levels that occurred in Arapoti, because white mold needs rainfall on flowers and soybean plant, as well as high relative humidity, for infection to occur (ABAWI et al, 1975; WEISS et al, 1980).

Regarding the values for severity of the disease, Figures 1B, 2B and 3B show that Arapoti had similar levels of severity to Pinhão (86 and $84 \%$ respectively in the control) and Mauá-da-Serra had lower values, with $57 \%$ in the control. This fact may be explained by the relative decrease in relative humidity and the increase in temperature in the period after flowering until grain filling that occurred in Mauá-da-Serra. These are unfavourable conditions for the development of white mold after infection and therefore they possibly explain the high incidence but low disease severity annoted in Mauá-da-Serra (Annexes 1, 2 and 3).

\section{Arapoti}

Regarding the values for the incidence of the disease in Arapoti, it was observed that the treatments 3 [Fl $(\mathrm{R} 1+\mathrm{R} 4)+\mathrm{Tm}(\mathrm{R} 2)] ; 5[\mathrm{Fl}$ $(\mathrm{R} 1+\mathrm{R} 2+\mathrm{R} 3)] ; 6$ [Pr (R1) + Tm (R2) + Fl (R4)]; 7 $[\mathrm{Ca}(\mathrm{V} 9+\mathrm{R} 2)+\mathrm{Fl}(\mathrm{R} 1+\mathrm{R} 4)] ; 15 \quad[\mathrm{Tm}+\mathrm{Fl}$ $(\mathrm{V} 9+\mathrm{R} 1+\mathrm{R} 2+\mathrm{R} 4)] \quad$ and $16 \quad[\mathrm{Ca}+\mathrm{Pr}$ 
$(\mathrm{V} 9+\mathrm{R} 1+\mathrm{R} 2+\mathrm{R} 4)]$ had the lowest rates and were different from the control (Figure 1A). No differences were observed for the variable of severity (Figure 1B).

\section{Arapoti}

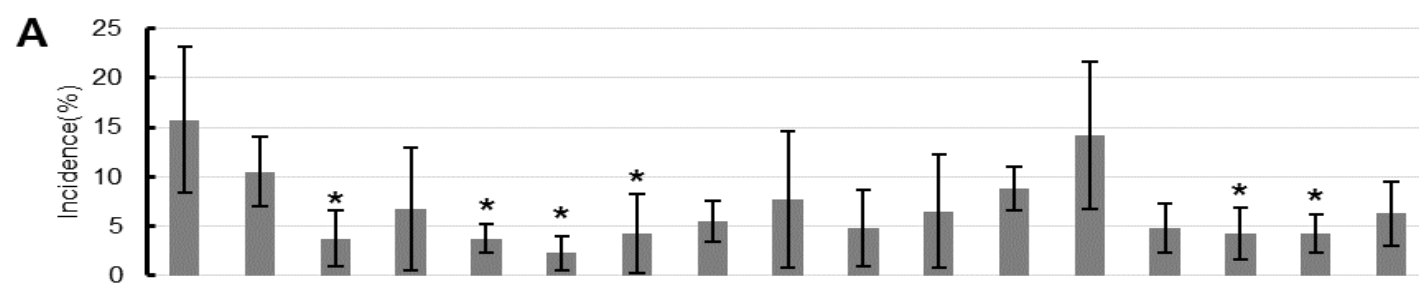

B
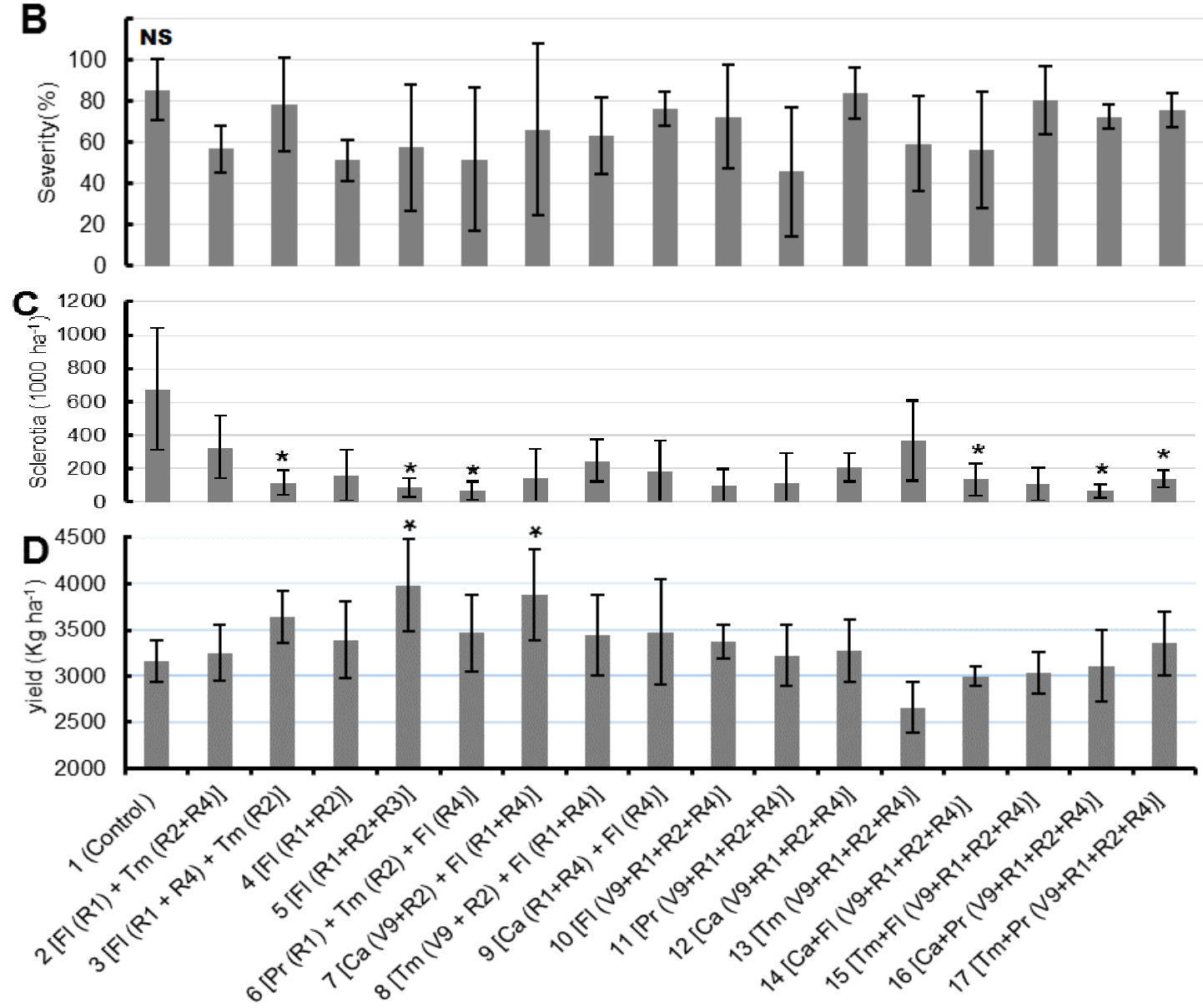

Figure 1. A. Average incidence of S. sclerotiorum (*statistically significant difference between the treatments and the control); B. Average severity of plants infected by S. sclerotiorum (NS: no statistically significant difference); $\mathbf{C}$. Sclerotia ha ${ }^{-1}$; D. Yield in $\mathrm{Kg} \mathrm{ha}^{-1}$. Arapoti, 2011-12 crop season.

In terms of the number of sclerotia produced (Figure 1C), it was observed that treatments $3[\mathrm{Fl}$ $(\mathrm{R} 1+\mathrm{R} 4)+\mathrm{Tm}(\mathrm{R} 2)] ; 5[\mathrm{Fl}(\mathrm{R} 1+\mathrm{R} 2+\mathrm{R} 3)] ; 6[\mathrm{Pr}$ $(\mathrm{R} 1)+\mathrm{Tm}(\mathrm{R} 2)+\mathrm{Fl}(\mathrm{R} 4)] ; 14[\mathrm{Ca}+\mathrm{Fl}$ (V9+R1+R2+R4)]; 16 [Ca+Pr (V9+R1+R2+R4)] and $17[\mathrm{Tm}+\operatorname{Pr}(\mathrm{V} 9+\mathrm{R} 1+\mathrm{R} 2+\mathrm{R} 4)]$ were different from the control, with a lower production of sclerotia in the plants infected by the disease.

Due to the low incidence that was recorded in Arapoti, large differences in the crop yield
(Figure 1D) were not observed, where only the treatments $5[\mathrm{Fl}(\mathrm{R} 1+\mathrm{R} 2+\mathrm{R} 3)]$ and $7[\mathrm{Ca}(\mathrm{V} 9+\mathrm{R} 2)+$ $\mathrm{Fl}(\mathrm{R} 1+\mathrm{R} 4)]$ were superior to the control.

\section{Mauá-da-Serra}

Mauá-da-Serra had the highest incidence level of white mold (Figure 2A), where it was observed that most of fungicide treatments resulted in lower levels of incidence, and only treatments 3 $[\mathrm{Fl}(\mathrm{R} 1+\mathrm{R} 4)+\mathrm{Tm}(\mathrm{R} 2)]$ and $11[\mathrm{Pr}$ 
$(\mathrm{V} 9+\mathrm{R} 1+\mathrm{R} 2+\mathrm{R} 4)]$ did not present differences compared to the control. No differences for the variable severity were observed between treatments. Similar results to that of incidence were observed in relation to the production of sclerotia, where only the treatments $3[\mathrm{Fl}(\mathrm{R} 1+\mathrm{R} 4)+\mathrm{Tm}(\mathrm{R} 2)] ; 8[\mathrm{Tm}$ $(\mathrm{V} 9+\mathrm{R} 2)+\mathrm{Fl}(\mathrm{R} 1+\mathrm{R} 4)]$ and $11[\mathrm{Pr}$ $(\mathrm{V} 9+\mathrm{R} 1+\mathrm{R} 2+\mathrm{R} 4)]$ did not present differences in relation to the control regarding the production of sclerotia (Figure 2C). As the estimated sclerotia production was measured in hectares, the treatments that had a higher incidence of the disease tended to have higher production of sclerotia per hectare.

Regarding the yield figures, due to the high incidence of white mold in the studied area, differences in yield were to be expected. However, as can be seen in Figure 2D, there were no differences between the treatments and the control.
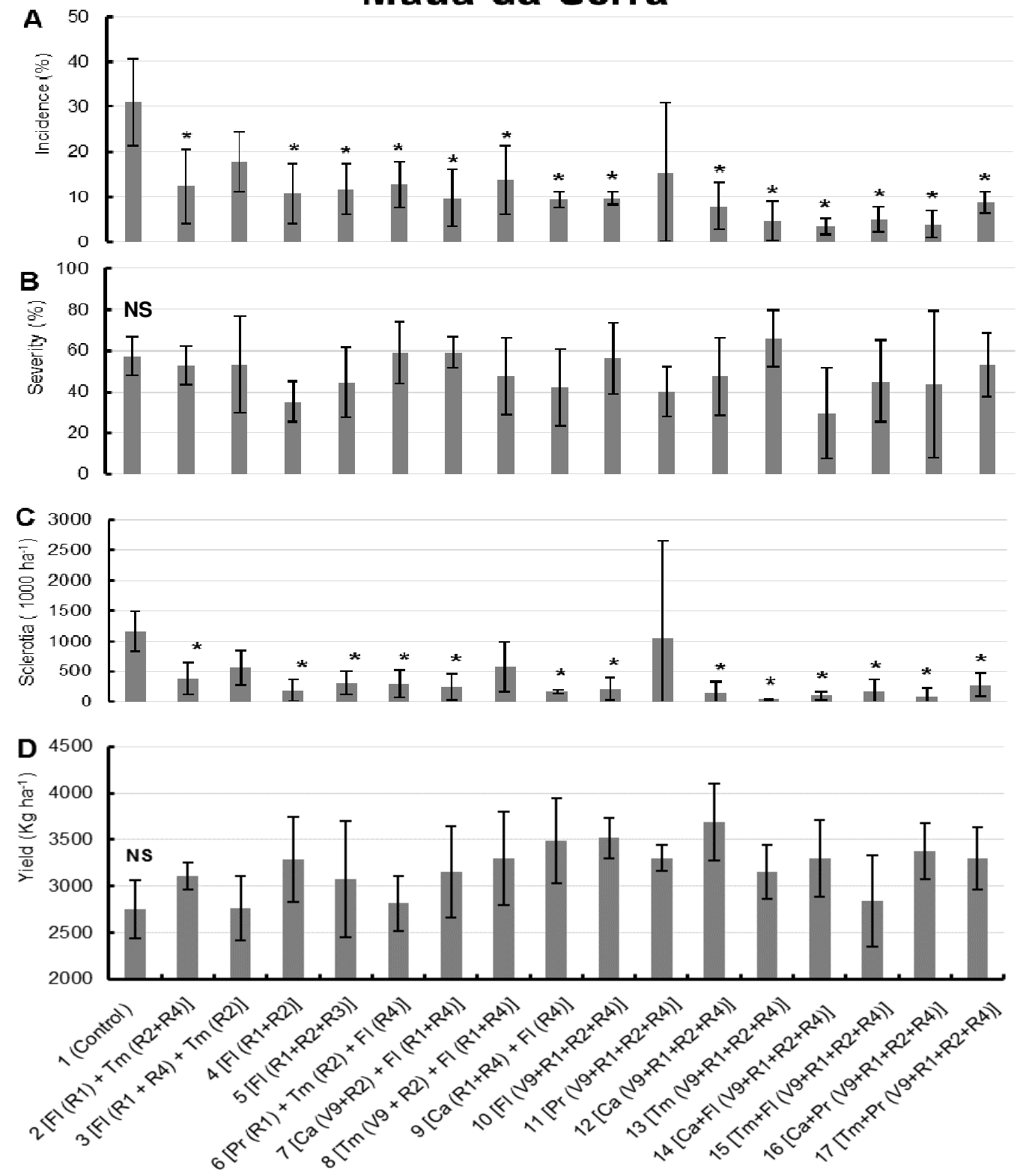

Figure 2. A. Average incidence of S. sclerotiorum (*statistically significant difference between the treatments and the control); B. Average severity of plants infected by S. sclerotiorum (NS: no statistically significant difference); C. Sclerotia ha' ${ }^{1}$; D. Yield in $\mathrm{Kg} \mathrm{ha}^{-1}$. Mauá-da-Serra, 2011-2012 crop season.

\section{Pinhão}

In Pinhão (Figure 3), similarly to what was observed in Mauá-da-Serra, most of the treatments with fungicide resulted in lower levels of incidence (Figure 3A), except for treatment $17[\mathrm{Tm}+\mathrm{Pr}$ (V9+R1+R2+R4)]. 


\section{A \\ Pinhão}
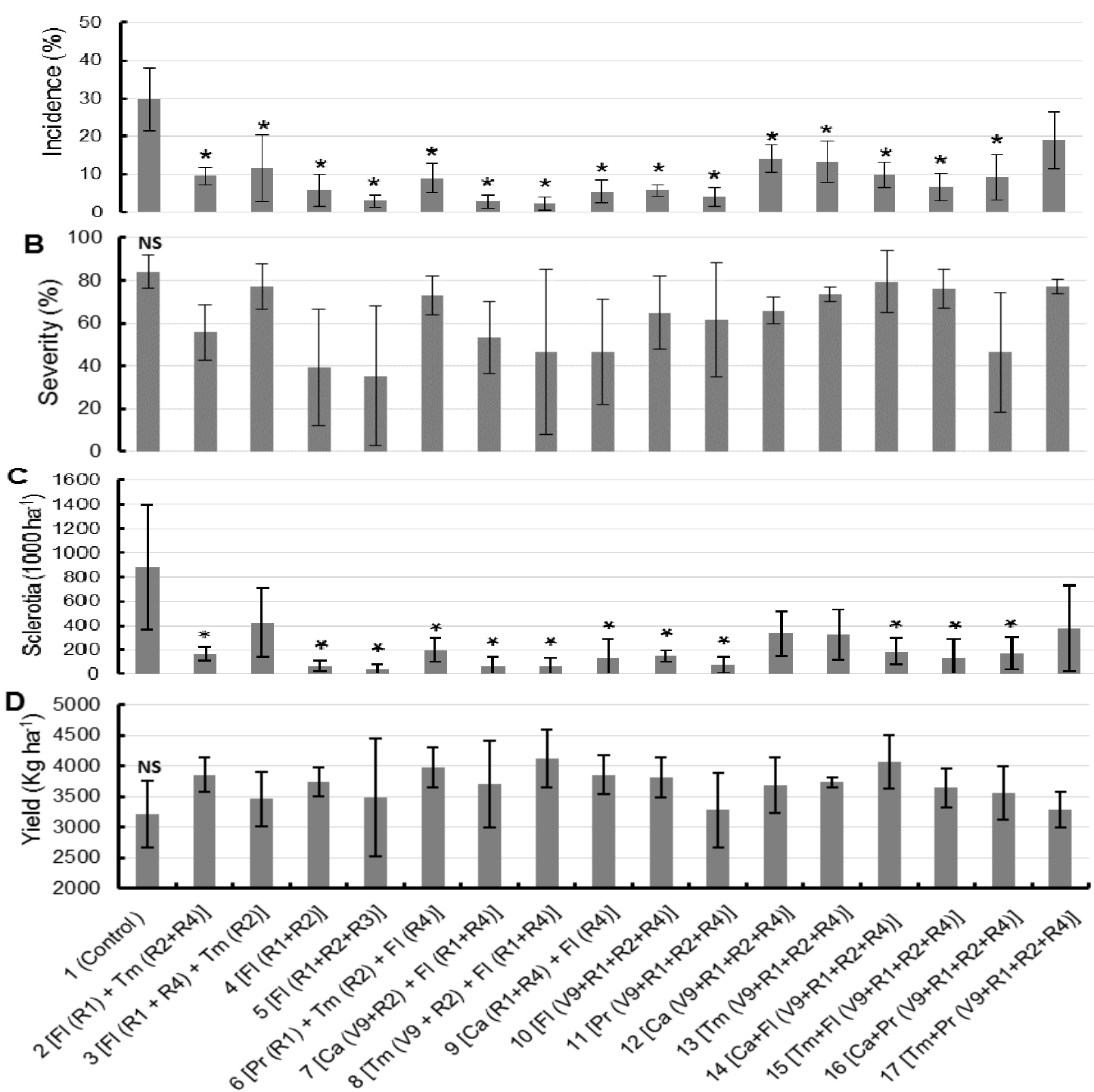

Figure 3. A. Average incidence of S. sclerotiorum (*statistically significant difference between the treatments and the control); B. Average severity of plants infected by S. sclerotiorum (NS: no statistically significant difference); C. Sclerotia ha ${ }^{-1}$; D. Yield in Kg ha ${ }^{-1}$. Pinhão, 2011-2012 crop season.

Figure 3B shows the data regarding the severity of white mold in Pinhão; no differences were observed between treatments despite the large numerical differences between them.

The data regarding the production of sclerotia (Figure 3C) showed that most of the fungicide treatments resulted in a lower number of sclerotia per hectare, with the exception of treatments $3[\mathrm{Fl}(\mathrm{R} 1+\mathrm{R} 4)+\mathrm{Tm}(\mathrm{R} 2)] ; 12[\mathrm{Ca}$ $(\mathrm{V} 9+\mathrm{R} 1+\mathrm{R} 2+\mathrm{R} 4)] ; 13$ [Tm $(\mathrm{V} 9+\mathrm{R} 1+\mathrm{R} 2+\mathrm{R} 4)]$ and $17[\mathrm{Tm}+\mathrm{Pr}(\mathrm{V} 9+\mathrm{R} 1+\mathrm{R} 2+\mathrm{R} 4)]$, which showed no difference when compared to the control.

Although most of the treatments reduced the incidence of the disease when compared to the control (Figure 3A), there were no statistical differences between the treatments and the control in relation to crop yield (Figure 3D).

These results demonstrate that the fungicides that were used provided lower levels of incidence and lower numbers of sclerotia per hectare in areas with high incidence of white mold on soybean (Mauá-da-Serra and Pinhão).

The results of this study are following those stand by Jaccoud Filho et al. (2010b) and Julliati et al. (2010) where applications of the fungicides fluazinam, procymidone, methyl thiophanate and carbendazim resulted in lower levels of incidence of white mold on soybean. However, a study by Muller 
et al. (2002) did not find an effective control of white mold on soybean using one or two applications of methyl thiophanate in flowering soybean, with doses from 0.84 to $1.12 \mathrm{~kg}$ a.i. $\mathrm{ha}^{-1}$ in three distinct locations. Nevertheless, Muller et al. (2004) observed efficient control using a dose of methyl thiophanate $1.12 \mathrm{~kg}$ a.i ha ${ }^{-1}$ applied at the R1 stage, with subsequent inoculation of $S$. sclerotiorum. Application of the same dose at the R3 stage, after the inoculation of the pathogen, did not provide any control of the disease. These results confirm the importance of applying fungicides at the correct growth stage in a preventive manner, and also the importance of adequate equipment to achieve good coverage of the soybean flowers, even in the lower third of the canopy.

The reduction in the incidence of white mold by using fungicides results in a lower production of sclerotia, which can initiate new epidemics in subsequent years. According to Steadman (1983), a single sclerotium can produce over 2,000,000 ascospores in a period of 10 days. These results show the great ability of $S$. sclerotiorum to infect, even from low inoculum density, as also demonstrated in a study by Schwartz and Steadman (1978), where only 0.2 sclerotia per $\mathrm{kg}$ of soil provided $46 \%$ incidence of white mold in beans. This emphasizes the need to reduce sclerotia production by using fungicides in order to reduce the inoculum present in the soil, thereby helping to control the disease in future crops.

\section{CONCLUSION}

Fungicides applied in soybean areas with historically white mold incidence up to $31 \%$ can reduce the disease incidence and sclerotia production levels.

RESUMO: O objetivo deste estudo foi o de verificar a eficiência de controle do mofo-branco na soja com o uso de diferentes fungicidas aplicados isoladamente, alternados, em diferentes estádios fenológicos e em mistura de dois princípios ativos, em três locais: Arapoti/PR, Mauá-da-Serra/PR e Pinhão/PR, Brasil. Os fungicidas utilizados foram carbendazim $(\mathrm{Ca})$, tiofanato metílico $(\mathrm{Tm})$, fluazinam $(\mathrm{Fl})$ e procimidona $(\mathrm{Pr})$. Os experimentos foram compostos por 17 tratamentos e 4 repetições distribuídas em blocos aleatorizados. As variáveis analisadas foram incidência, severidade, produção de escleródios e o rendimento da cultura. Mauá-da-Serra e Pinhão apresentaram as maiores incidências, $31 \%$ e $29,8 \%$ no tratamento controle, respectivamente, onde a maioria dos tratamentos com fungicidas proporcionou menor incidência e produção de escleródios, quando comparados ao controle, porém sem diferenças quanto ao rendimento. Em Arapoti foi observada a menor incidência, $15,8 \%$ no controle, onde a maioria dos tratamentos com fungicidas não apresentou diferenças para incidência, produção de escleródios e rendimento, quando comparados ao controle. Em nenhum dos três locais foram verificadas diferenças entre os tratamentos e o controle para a variável severidade. Como conclusão, fungicidas aplicados em áreas de soja com histórico de incidência de mofo-branco de até $31 \%$ podem reduzir a incidência da doença e o nível de produção de escleródios.

PALAVRAS-CHAVE: Sclerotinia sclerotiorum (Lib.) De Bary. Glycine max L. Escleródios. Fungicidas.

\section{REFERENCES}

ABAWI, G. S, et al. Infection of bean by ascospores of Whetzelinia sclerotiorum. Phytopathology, Saint Paul, v. 65 , p. 673-678, 1975. Disponível em: < http://www. apsnet.org/publications/phytopathology/backissues/ Documents/1975Abstracts/Phyto65_673. > Acesso em: 12. Jan. 2013. DOI: 10.1094/Phyto-65-673.

ABAWI, G. S.; GROGAN, Epidemiology of diseases caused by Sclerotinia species. The American Phytophatological Society, Saint Paul, v. 69, n. 8, 1979.

ALMEIDA, A. M. R, et al. Doenças da Soja (Glycine max). In: KIMATI, H.; AMORIN, L.; REZENDE, J. A. M.; BERGAMIN FILHO, A.; CAMARGO, L. E. A. Manual de Fitopatologia: Doenças das Plantas Cultivadas. 4 ed. São Paulo - SP: Agronômica Ceres Ltda, v. 2. 2005.

BOLAND, G. J.; HALL, R. Index of plant hosts of Sclerotinia sclerotiorum. Canadian Journal of Plant Pathology, Guelph, v. 16, p. 93-108, 1994. Disponível em: <http://www.tandfonline.com/doi/ref/10.1080/ 07060669409500766\#tabModule> Acesso em: 14. Jan. 2013. DOI: 10.1080/07060669409500766. 
COLEY-SMITH, J. R.; COOKE. R. C. Survival and germination of fungal sclerotia. Annual Review of Phytopathology, Saint Paul, v. 9, p. 65-92, 1971.

FEHR, W. R.; CAVINESS, C. E. Stages of soybean development. Ames: IOWA State University. 1977.

FERREIRA, L. P.; LEHMAN, P. S.; ALMEIDA, A. M. R. Doenças da Soja no Brasil. Londrina: EmbrapaCNPSo, 1979. $42 \mathrm{p}$.

GOULART, A. C. P. Fungos em sementes de soja: detecção, importância e controle. Dourados: EMBRAPA AGROPECUÁRIA OESTE, 2005.

GRAU, C. R.; HARTMAN, G. L. Sclerotinia Stem Rot. In: HARTMAN, G. L.; SINCLAIR, J. B.; RUPE, J. C. Compendium of Soybean diseases. 4 ed. Saint Paul: American Phytopathological Society, 1999, p. 46-48.

JACCOUD FILHO, D. S. et al. Análise, distribuição e quantificação do "Mofo Branco" em diferentes regiões produtoras do estado do Paraná. (Resumo). In: XXXI Reunião de Pesquisa de Soja da Região Central do Brasil - Resumos. Londrina: EMBRAPA SOJA, 2010a. p. 226 - 228. Disponível em: <http://www.cnpso.embrapa.br/download/Resumos_2010_online.pdf> Acesso em: 10 Jan. 2013.

JACCOUD FILHO, D. S. et al. Avaliação da eficácia e do manejo de fungicidas no controle do mofo branco (Sclerotinia sclerotiorum) na cultura da soja. In: XXXI Reunião de pesquisa de soja da região central do Brasil, 2010, Brasília. Resumos da XXXI reunião de pesquisa de soja da região central do Brasil. Brasília: Embrapa soja, 2010b, p. 189-191. Disponível em: http://www.cnpso.embrapa.br/download/Resumos _2010_online.pdf Acesso em: 10 Jan. 2013.

JULIATTI, F. C.; JULIATTI, F. C. A. Podridão branca da haste da soja: manejo e uso de fungicidas em busca da sustentabilidade nos sistemas de produção. Uberlândia: Composer, 2010. 33 p.

MUELLER, D. S, et al. Efficacy of fungicides on Sclerotinia sclerotiorum and their potential for control of Sclerotinia stem rot on soybean. Plant Disease, Saint Paul, v. 86, p.26-31, 2002. Disponível em: $<\mathrm{http} / / /$ apsjournals.apsnet.org/doi/pdf/10.1094/PDIS.2002.86.1.26>Acesso $\quad$ em: 13 Jan. 2013. Doi: 10.1094/PDIS.2002.86.1.26.

MUELLER, D. S. et al. Application of thiophanate-methyl at different host growth stages for management of sclerotinia stem rot in soybean. Crop Protection, Surrey, n. 23, v. 10, p. 983-988, 2004. Disponível em: < http://herman.marc.usda.gov/SP2UserFiles/ad_hoc/54000000WhiteMoldResearch/PublicationPDFs/Applicatio nofthiophanate.pdf> Doi:10.1016/j.cropro.2004.02.013.

NAPOLEÃO, R. et al. Intensidade do mofo-branco do feijoeiro em plantio convencional e direto sob diferentes lâminas d'água. Fitopatologia Brasileira, Brasília, v. 30, p. 374-379, 2005.

PIERRE, M. L. C. Influência de épocas de semeadura e cultivares na incidência do mofo branco na cultura da soja. Dissertação (Mestrado em Agronomia), Universidade Estadual de Ponta Grossa, Ponta Grossa, 2015.

SCHWARTZ, H. F.; STEADMAN, J. R. Factors affecting sclerotium populations and apothecium production by Sclerotinia sclerotiorum. Phytopathology. Saint Paul, v. 68, p. 383-388, 1978. Disponível em: < http://www.apsnet.org/publications/phytopathology/backissues/Documents/1978Articles/Phyto68n03_383.pdf> Acesso em: 10 Jan. 2013.

STEADMAN, J. R. White mold: a serious yield-limiting disease of bean. Plant Disease. Saint Paul, v. 67, n. 4, p. 346 - 350, 1983. Disponível em: < http://www.apsnet.org/publications/PlantDisease/BackIssues/ Documents/1983Abstracts/PD_67_346.htm > Acesso em: 10 Jan. 2013. Doi: 10.1094/PD-67-346. 
ZENG, W, et al. Use of Coniothyrium minitans and other microorganisms for reducing Sclerotinia sclerotiorum. Biological Control. Amsterdam, v. 60, n. 2, p. 225-232, 2012. Disponível em: < http://www.sciencedirect.com/science/article/pii/S104 $9964411002970>$ Acesso em: 10 Jan. 2013. Doi: 10.1016/j.biocontrol. 2011.10.009

WEISS, A. et al. Comparison of within-canopy microclimate and white mold disease (Sclerotinia sclerotiorum) development in dry edible beans as influenced by canopy structure and irrigation. Agricultural Meteorology. Davis, v. 22, p. 11-21, 1980.

YIN, Y., et al. A multiplex allele-specific PCR method for the detection of carbendazim-resistant Sclerotinia sclerotiorum. Pesticide Biochemistry and Physiology. v. 97, n. 1, p. 36-42. 2010. Disponível em: < http://www.Sciencedirect.com/science/article/pii/S0048357509001667> Acesso em: 14 Jan. 2013. Doi: http://dx.doi.org/10.1016 /j.pestbp.2009.12.002 
ANNEXES

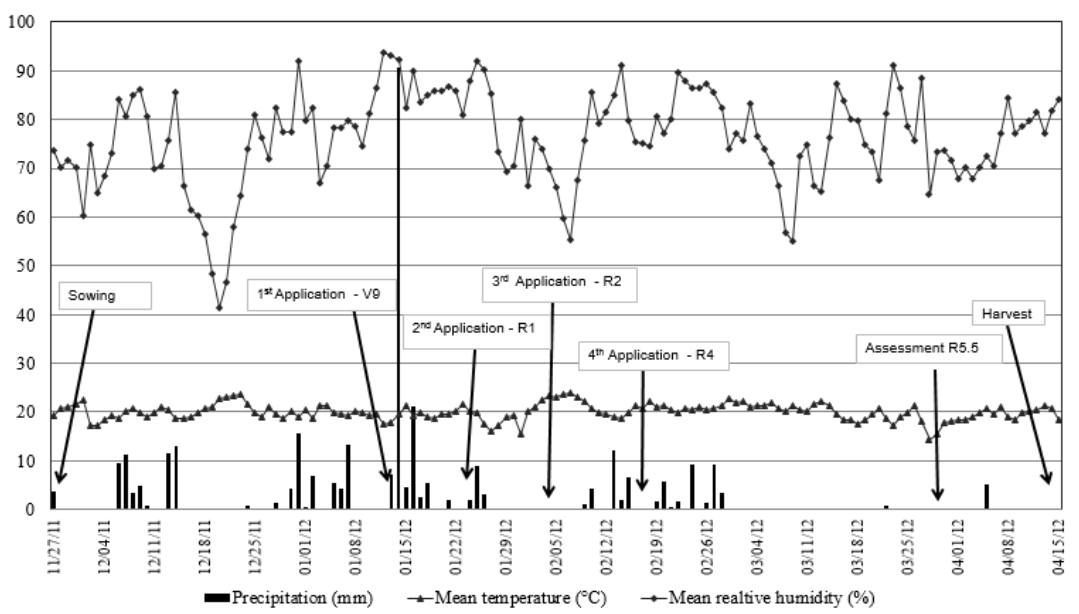

Annexe 1. Meteorological data for Arapoti, PR in the 2011-2012 crop season. V9: ninth node; R1: first open flower; R2: full bloom; R4: full pod development; R5.5: end of grain filling. Source: SIMEPAR.

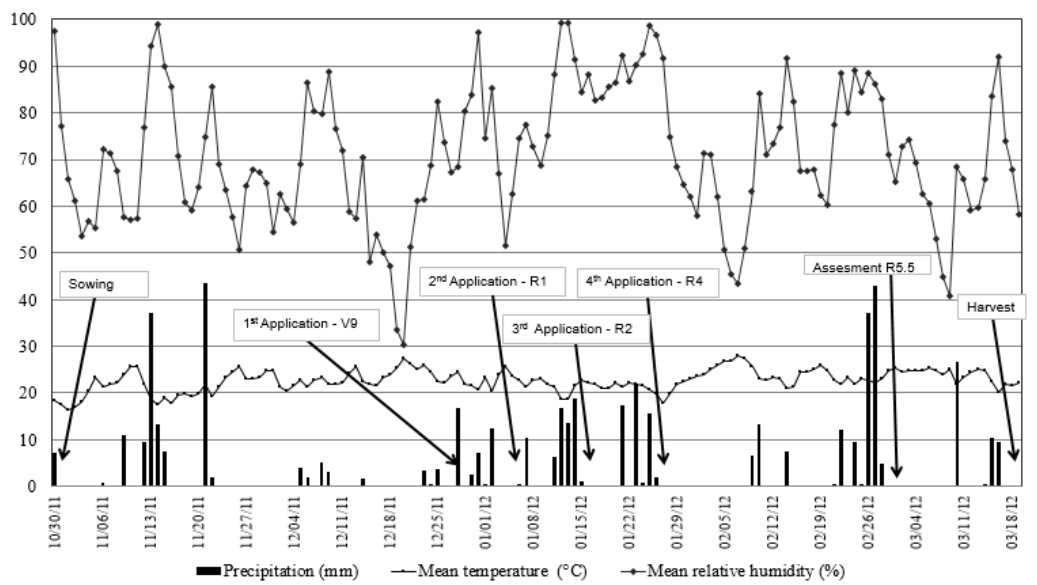

Annexe 2. Meteorological data from Apucarana,PR, 2011-2012 crop season, used as a reference for experiment conducted in Mauá-da-Serra, PR. V9: ninth node; R1: first open flower; R2: full bloom; R4: full pod development; R5.5: end of grain filling. Source: SIMEPAR.

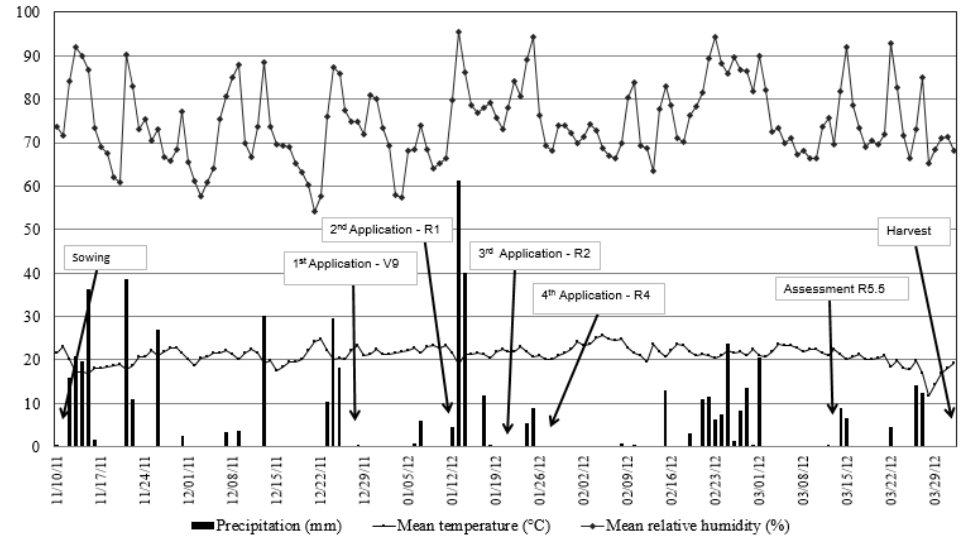

Annexe 3. Meteorological data for Pinhão, PR in the 2011-2012 crop season. V9: ninth node; R1: first open flower; R2: full bloom; R4: full pod development; R5.5: end of grain filling. Source: SIMEPAR. 